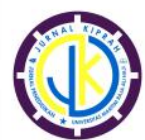

http://ojs.umrah.ac.id/index.php/kiprah/index

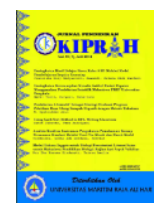

\title{
Eksplorasi Etnomatematika pada Gerakan Pukulan Seni Pencak Silat Kepulauan Riau
}

\author{
Rahmat Wastio Wicaksono, Nur Izzati", Linda Rosmery Tambunan \\ Pendidikan Matematika, Universitas Maritim Raja Ali Haji, Tanjungpinang, Kepulauan Riau, Indonesia \\ Pengiriman: 11/11/2019; Diterima: 27/05/2020; Publikasi: 30/06/2020 \\ DOI: https://doi.org/10.31629/kiprah.v8i1.1596
}

\begin{abstract}
Abstrak
Pencak silat telah diwariskan oleh nenek moyang sebagai salah satu budaya Indonesia yang perlu dilestarikan, dibina, dan dikembangkan. Pencak silat memiliki unsur kesenian dan juga praktik matematis di dalamnya. Penelitian ini bertujuan untuk mendeskripsikan etnomatematika yang terdapat pada gerakan pukulan seni pencak silat Kepulauan Riau. Penelitian ini menggunakan pendekatan kualitatif dengan jenis penelitian etnografi. Data diperoleh dari seorang narasumber yaitu Bapak Rahmad dan Bapak Zul Rozali dengan teknik pengumpulan data berupa wawancara, observasi, dan dokumentasi serta instrumen utama yaitu human instrument. Data dianalisis dengan rancangan Spradley: analisis domain, taksonomi, komponensial, dan tema budaya. Hasil penelitian menunjukkan adanya temuan etnomatematika berupa bangun datar segitiga, sudut lancip, tumpul, dan sudut siku-siku, serta garis berpotongan dan garis saling tegak lurus.
\end{abstract}

Kata kunci: eksplorasi; etnomatematika; gerakan pukulan; seni pencak silat

\begin{abstract}
The martial arts has been passed down by ancestors as one of Indonesia's cultures that needs to be preserved, nurtured and developed. In martial arts there are elements of art and also mathematical practices in it. This research aims to describe ethnomatemics contained in the Riau Islands martial arts punch movements. This research uses a qualitative approach with ethnographic research types. Data obtained from a resource person, Mr. Rahmad and Mr. Zul Rozali with data collection techniques in the form of interviews, observations, and documentation as well as the main instrument, namely human instruments. Data were analyzed with Spradley's design: domain analysis, taxonomy, compatibility and cultural themes. The results showed ethnomatemics findings in the form of a triangular flat figure, acute angle, obtuse angle, and right angle, as well as intersecting lines and perpendicular lines.
\end{abstract}

Keywords: exploration; ethnomatematics; punch movements; martial arts

\section{PENDAHULUAN}

Indonesia adalah salah satu negara berkembang dari puluhan negara berkembang lainnya. Pascakemerdekaan hingga sekarang, Indonesia masih terus berbenah diri untuk terus melakukan yang terbaik bagi kehidupan masyarakat. Untuk itu, pemerintah selalu melakukan pembaruan dan mengembangkan sektor-sektor potensial di Indonesia, mulai dari sektor pendidikan, kesehatan, ekonomi, pariwisata bahkan juga olahraga, baik dalam segi sarana maupun prasarana yang mendukung sektor-sektor tersebut. Salah satu bagian dari beberapa sektor tersebut adalah pencak silat.

Pencak silat di Indonesia telah berkembang dari zaman kerajaan hingga sekarang. Pencak silat menjadi ilmu beladiri 
yang sangat terkenal di kalangan masyarakat. Menurut Suhartono (2011), pencak silat dikenal sebagai budaya beladiri khas Indonesia yang di dalamnya terdapat 4 aspek pembinaan bernilai tinggi, yakni aspek seni, bela diri, mental spiritual, dan olahraga.

Pencak silat dikenal sebagai warisan budaya beladiri khas Indonesia yang memiliki nilai kesenian, pengetahuan dan pembelajaran. Hal ini menjadikan pencak silat sangat dekat dengan kehidupan dan lingkungan tempat berkembangnya pencak silat tersebut. Selanjutnya, PB IPSI beserta BAKIN dalam Mulyana (2013) mendefinisikan bahwa pencak silat adalah hasil budaya manusia Indonesia untuk membela, mempertahankan eksistensi (kemandiriannya) dan integritasnya (manunggal) terhadap lingkungan hidup/alam sekitarnya untuk mencapai kesadaran hidup guna meningkatkan iman dan takwa kepada Tuhan Yang Maha Esa.

Beranjak dari hal di atas, kehidupan manusia saat ini sangat erat kaitannya dengan pembelajaran, terutama pembelajaran matematika. Matematika adalah sebuah ilmu pasti yang terbentuk berdasarkan akal yang berhubungan dengan benda-benda serta pikiran yang abstrak, yang dapat dipelajari dalam berbagai aspek (Afriyanty, 2019). Selain nilai seni yang menjadi andalan pada pencak silat, kesenian ini juga memiliki beragam praktik matematis di dalamnya yang jarang dipandang oleh para penikmat silat. Hal ini memperkuat alasan peneliti untuk mulai mengkaji seni pencak silat sehingga ditemukan praktik matematis yang terselip di dalamnya.

Penelitian terdahulu yang pernah dilakukan terkait praktik matematis dalam sebuah seni dilakukan oleh Afriyanty \& Izzati (2019). Penelitian tersebut mengkaji etnomatematika pada corak alat musik kesenian Marawis dengan domain merancang. Dalam penelitian tersebut ditemukan adanya praktik matematis berupa konsep transformasi geometri.

Selain pada Kesenian Marawis, kesenian lain yang mengandung praktik matematis juga ditemukan pada penelitian yang dilakukan oleh Nurhikmah, Febrian, \& Fera (2019). Hasil penelitiannya menunjukkan adanya konsep matematika sekolah pada ragam corak ukiran khas Melayu Kepulauan Riau, yaitu bangun datar dan bangun ruang, pecahan, perbandingan, kekongruenan, simetri, dan tansformasi geometri.

Praktik matematis juga ditemukan pada permainan lokal yaitu pada penelitian yang dilakukan oleh Febrian (2016). Hasil penelitiannya menunjukkan bahwa pembuatan layang-layang Wau memanfaatkan pengukuran panjang sebagai topik dasar matematika di sekolah. Selain itu, pembuatan corak tenun melayu menggunakan teknik yang akrab dengan topik matematika seperti transformasi geometri (translasi, rotasi, refleksi, dan dilatasi). Praktik matematis yang ditemukan pada kesenian dan budaya seperti pada penelitian terdahulu disebut sebagai Etnomatematika.

D'Ambrossio pertama kali memperkenalkan istilah etnomatematika pada tahun 1985, dimana D'Ambrosio dalam Atmidasari (2017), Desmawati (2018), dan Nuh (2016) menyatakan bahwa etnomatematika yakni matematika yang dipraktikkan di antara kelompok budaya, anak dengan usia tertentu, kelas profesional dan sebagainya. Melalui pemikiran D'Ambrosio ini, pembelajaran matematika sedang berkembang dengan tetap menjaga warisan kebudayaan masyarakat setempat, khususnya dalam ikatan adat-istiadat.

Sirate (2011) D'Ambrosio mendefinisikan beberapa domain atau aktivitas matematika dalam kehidupan sehari-hari, di antaranya adalah aktivitas berhitung, mengelompokkan, merancang bangunan atau alat, mengukur, membuat pola, membilang, menentukan lokasi, bermain, menjelaskan, dan sebagainya. Domain tersebut nantinya akan berperan penting dalam menentukan temuan etnomatematika.

Untuk membantu proses penggalian dan pengkajian informasi mengenai etnomatematika, peneliti akan melakukan 
eksplorasi. Eksplorasi dalam Kamus Bahas Indonesia diartikan sebagai penjelajahan lapangan dengan tujuan memperoleh pengetahuan lebih banyak tentang keadaan terutama sumber-sumber alam yang terdapat di tempat itu. Menurut Purwadi dalam Desmawati (2018) menyatakan bahwa eksplorasi adalah suatu aktivitas yang dilakukan dengan menggali infromasi atau alternatif yang sebanyakbanyaknya untuk hal yang berkaitan dengan kepentigan masa mendatang.

Berdasarkan latar belakang masalah yang dipaparkan, peneliti melakukan penelitian yang berjudul "Eksplorasi Etnomatematika pada Gerakan Pukulan Seni Pencak Silat Kepulauan Riau" dengan tujuan untuk mendeskripsikan Etnomatematika yang ditemukan pada gerakan pukulan Seni Pencak Silat Kepulauan Riau.

\section{METODE PENELITIAN}

Penelitian ini berjenis etnografi dengan pendekatan kualitatif. Jenis penelitian etnografi yang dipilih bertujuan untuk mengamati dan menguraikan suatu budaya dalam masyarakat secara keseluruhan sedangkan pendekatan kualitatif bertujuan untuk mendeskripsikan proses hingga hasil penelitian ditemukan dalam bentuk representasi kata dan gambar. Hal ini diperkuat oleh Creswell (2012) mendefinisikan etnografi merupakan prosedur penelitian kualitatif untuk menggambarkan, menganalisa, dan menafsirkan unsur-unsur dari sebuah kelompok budaya seperti pola perilaku, kepercayaan, dan bahasa yang berkembang dari waktu ke waktu.

Tempat dilakukannya penelitian ini yaitu di rumah guru besar perguruan Sendeng Cekak, yaitu di Jalan Sei Jang. dengan jangka waktu pada bulan Juni 2019 hingga Juli 2019. Subjek pada penelitian ini adalah pesilat di perguruan Sendeng Cekak Tanjungpinang. Penentuan subjek dilakukan dengan snowball sampling. Menurut Lestari (2015) snowball sampling merupakan teknik penentuan sampel yang mula-mula kecil, kemudian membesar. Sehingga pada penelitian ini penentuan subjek dengan cara meminta pertimbangan informan sebelumnya kepada siapa lagi yang dapat memberikan informasi yang lebih detail.

Pengumpulan data dilakukan dengan triangulasi teknik, yaitu dengan melakukan observasi, wawancara, dan dokumentasi dengan instrumen utama yaitu human instrument. Sebagai instrumen utama, peneliti berperan dalam memilih informan sebagai sumber data, menetapkan fokus penelitian, melakukan pengumpulan data, menafsirkan data, serta membuat kesimpulan atas hasil temuannya. Selain itu juga digunakan instrumen pendukung berupa lembar observasi, dan pedoman wawancara.

Analisis data menggunakan teknik dengan rancangan Spradley. Dalam Sugiyono (2014) dan Sanapiah dalam Sarwono (2006) dipaparkan bahwa Spradley membagi analisis data menjadi empat yaitu analisis domain, analisis taksonomi, analisis komponensial, dan analisis tema budaya. Langkah akhir adalah melakukan pengecekan keabsahan data dengan perpanjangan pengamatan, peningkatan ketekunan, triangulasi teknik serta triangulasi sumber pengumpulan data.

Untuk mencapai tujuan penelitian, maka peneliti menggunakan langkahlangkah prosedur penelitian sebagai berikut:

1. Menentukan situasi sosial yaitu memilih informan dan aktivitas informan yang akan diteliti.

2. Mempersiapkan pedoman wawancara dan lembar observasi.

3. Melakukan pengambilan data terhadap informan melalui observasi, wawancara, dan dokumentasi.

4. Melakukan analisis domain berdasarkan data yang diperoleh, yaitu dengan wawancara, dokumentasi, maupun observasi. Dalam analisis domain, dilakukan reduksi data untuk memudahkan peneliti dalam memilah data yang berhubungan dengan penelitian dan menemukan aktivitas/domain etnomatematika. 
5. Melakukan analisis taksonomi untuk mendapatkan data lebih rinci berdasarkan penetapan domainnya.

6. Melakukan analisis komponesial, yaitu dari hasil analisis taksonomi dibantu dengan hasil dari pengambilan data sebelumnya untuk menggali ciri-ciri yang lebih spesifik dari apa yang diteliti.

7. Melakukan analisis tema budaya pada komponen yang telah ditetapkan pada analisis komponesial untuk memperoleh temuan etnomatematika.

8. Uji keabsahan data dilakukan untuk memastikan temuan yang diperoleh valid yang ditandai kesamaan informasi yang diperoleh pada penelitian.

9. Memperoleh temuan etnomatematika pada seni pencak silat yang sesuai dengan tujuan yang telah ditetapkan peneliti.

\section{HASIL DAN PEMBAHASAN}

Wawancara dilakukan sebanyak tiga kali bertempat di rumah guru besar sekaligus pendiri perguruan silat Sendeng Cekak, yaitu pada pada 26 Juni 2019, dilanjutkan pada 1 Juli 2019, dan terakhir pada 4 Juli 2019. Selama wawancara dilakukan, peneliti menggunakan perekam sebagai alat bantu dan pedoman wawancara sebagai panduan pertanyaan yang akan ditanyakan, serta kamera handphone untuk dokumentasi.

Perguruan silat Sendeng Cekak telah berdiri sejak 2003 dan berbadan hukum sejak tahun 2013 di bawah naungan IPSI Kota Tanjungpinang. Secara umum, pesilat Sendeng Cekak diajarkan seni silat yang juga berlaku secara nasional seperti seni silat tunggal baku dan seni wiraloka serta teknik gerak tangan dan kaki lainnya. Secara khusus, pesilat juga diajarkan seni silat yang diajarkan turun temurun dari nenek moyang yang sekarang masih diajarkan di perguruan silat Sendeng Cekak. Dalam Sendeng terdapat dua belas gerakan yang diturunkan sejak datuk zaman dahulu yang berhubungan dengan dunia dan akhirat karena gerakan tersebut dilandasi dengan dua kalimat syahadat.

Sejalan dengan perkembangan waktu, gerakan dua belas tersebut berganti menjadi tiga belas gerakan sama halnya dengan tiga belas rukun shalat (dalam Islam), dikarenaka gerakan silat ini berlandaskan spiritual. Pada seni pencak silat Sendeng Cekak Gerakan utama terletak pada gerakan tangan pesilat, karena penggunaan gerakan kaki (tendangan) dalam seni silat Sendeng Cekak dianggap kurang sopan. Gerakan tangan yang telah diperagakan oleh informan pada gerakan seni Hang Jebat dan Hang Tuah terbagi atas tiga belas gerakan.

\section{Hasil Observasi dan Dokumentasi pada Seni Pencak Silat}

Observasi dan dokumentasi yang dilakukan oleh peneliti adalah mengamati gerakan seni silat khas Sendeng Cekak. Gerakan seni silat diperagakan oleh dua pesilat, Bapak Rahmad dan Bapak Zul Rozali. Bapak Zul Rozali memperagakan gerakan sembilan dari gerakan Hang Tuah dan Bapak Rahmad memperagakan seni silat gerakan Hang Jebat. Di bawah ini adalah contoh dari gerakan Hang Tuah.

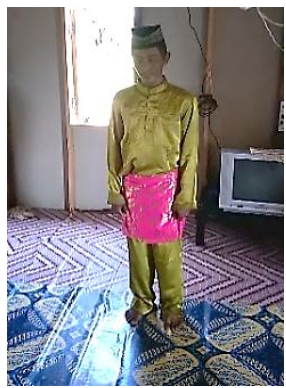

(a)

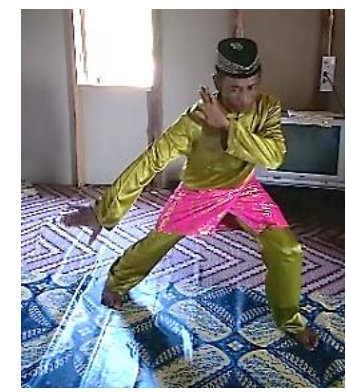

(b)
Gambar 1. Tahap Awal Gerakan Hang Tuah (a) Sikap Tegak dan (b) Kuda-kuda Samping

Gerakan Hang Tuah biasa diperagakan untuk pertunjukan dalam suatu acara. Seni silat Hang Tuah atau biasa disebut Gerakan Tujuh, merupakan turunan seni silat dari Datuk Laksamana Hang Tuah. Selanjutnya contoh dari gerakan Hang Jebat. 


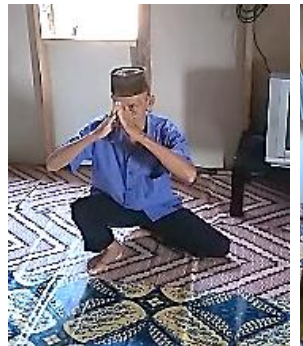

(a)

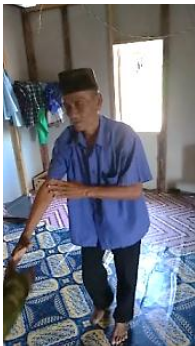

(b)

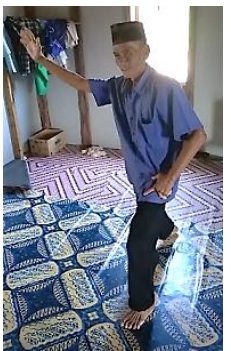

(c)
Gambar 2. Tahap Awal Gerakan Hang Jebat (a) Sikap Duduk, (b) Sikap Penghormatan, dan (c) Kudakuda Depan

Gerakan Hang Jebat yang biasa diperagakan untuk menyambut tamu penting pada suatu acara. Seni silat Hang Jebat atau biasa disebut Gerakan Dua Belas, merupakan turunan seni silat dari Datuk Laksamana Hang Jebat. Berdasarkan gerakan awal yang dicontohkan, peneliti melakukan pengamatan lanjutan pada gerakan pukulan tangan dan pola langkah gerakan Hang Jebat sebanyak 13 gerakan yang dipaparkan sebagai berikut.

\section{a. Gerakan Pukulan Tangan}

1. Tangkisan

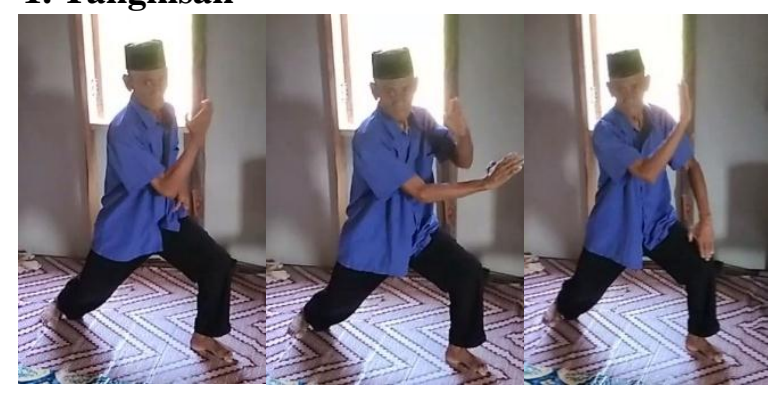

Gambar 3. Tangkisan

Pada gerakan tangkisan, pesilat menggunakan kuda-kuda samping kiri dengan tangan kanan ditekuk di depan dada untuk menghalau pukulan yang akan diberikan Kemudian tangan kanan pesilat bergerak ke bawah lalu menangkis pukulan yang masuk menuju ke samping kanan.

\section{Tangkisan Mengelak Pukulan Dalam}
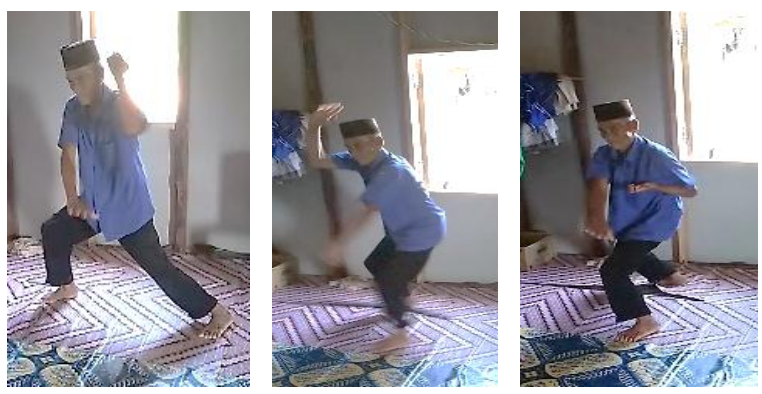

Gambar 4. Tangkisan Mengelak Pukulan Dalam Pada gerakan tangkisan mengelak pukulan, pesilat menggunakan kuda-kuda samping kanan dengan tangan kanan menghalau pukulan yang akan masuk ke tubuh depan. Selanjutnya pesilat memindahkan posisi kaki kanan ke belakang dan menggunakan kuda-kuda depan dengan tangan kiri menangkis pukulan selanjutnya.

\section{Tangkisan Memasukkan Pukulan}

Pada gerakan tangkisan memasukkan pukulan, gerakan tangan kanan terlihat seakan-akan menahan pukulan. Lalu tangan kanan mendorong maju pukulan tersebut dan tangan kiri naik menangkis ke arah atas pukulan tersebut. Kemudian memasukkan pukulan pada lawan yang telah ditangkis pukulannya.
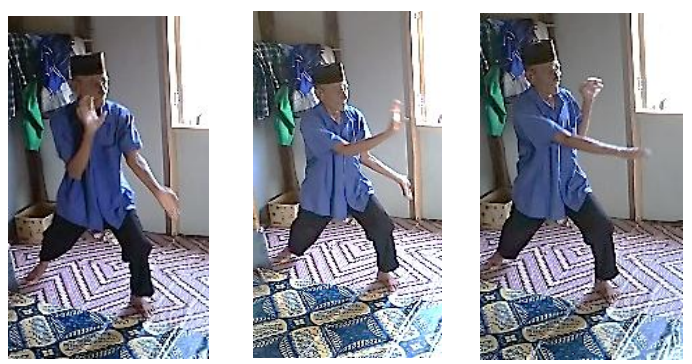

Gambar 5. Tangkisan Memasukkan Pukulan

\section{Menangkis Pukulan}

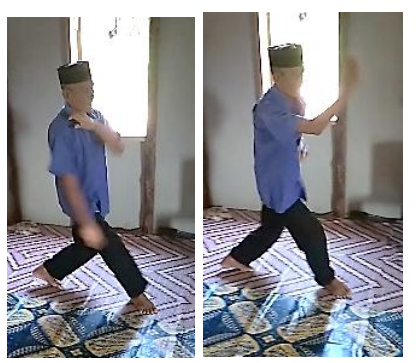


Padabar 6. Menanangkis Pukulan menangkis pukulan, gerakan dilakukan dengan mengarahkan tangan kanan dari bawah untuk menangkis dan mementalkan ke atas pukulan yang dilakukan.

\section{Tangkisan adalah Maut Bagi Pukulan}

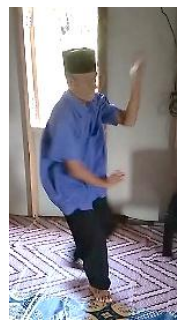

Gambar 7. Menangkis Pukulan

Pada gerakan tangkisan maut bagi pukulan terdiri dari pukulan yang ditangkis menggunakan tangan kiri, sedangkan tangan kanan sudah siap untuk melaksanakan gerakan selanjutnya.

\section{Mematikan Pukulan}

Gerakan mematikan pukulan merupakan lanjutan dari gerakan tangkisan maut bagi pukulan, pesilat saat menahan pukulan dengan tangan kiri kemudian menjepitnya dengan tangan kanan yang bergerak dari bawah ke atas.

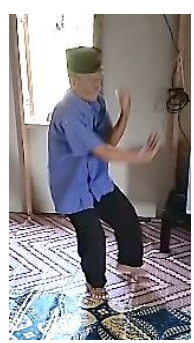

Gambar 8. Mematikan Pukulan

\section{Menapiskan Pukulan}
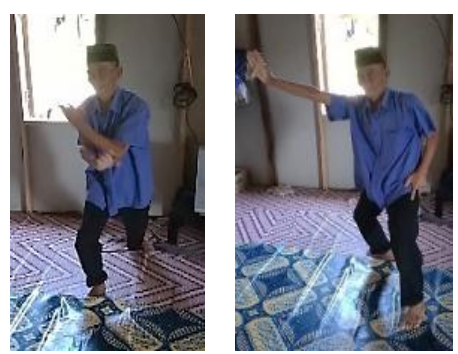

Gambar 9. Menapiskan Pukulan
Pada gerakan menapiskan atau menepis pukulan, gerakan dilakukan dengan menyilangkan tangan di depan dada dengan tangan kanan di arah kiri bawah dan tangan kiri berada di dekat bahu kanan atas. Ketika pukulan hampir mengenai tubuh, tangan kanan segera bergerak membuka ke atas, sehingga pukulan dapat ditepis.

\section{Mematikan Pukulan Tendangan Kaki}
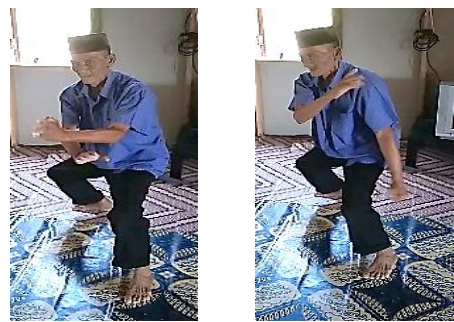

Gambar 10. Mematikan Pukulan Tendangan Kaki

Pada gerakan mematikan pukulan tendangan kaki, didahului dengan menahan tendangan kaki dari bawah menggunakan tangan kanan dan memperberat tangan kanan dengan tangan kiri yang disilangkan di atasnya. Selanjutnya, tangan kiri mengibas atau menepiskan tendangan kaki yang sudah ditahan.

\section{Membunuh Pukulan}

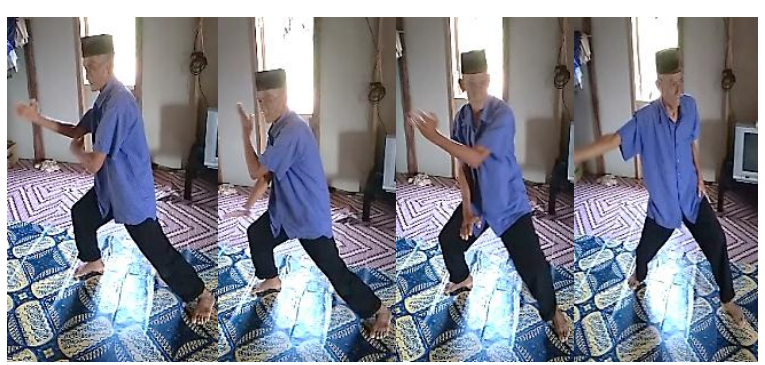

Gambar 11. Membunuh Pukulan

Pada gerakan membunuh pukulan, pesilat menggunakan kuda-kuda samping kanan dengan gerakan memotong pukulan lawan yang mengarah ke dada.

\section{Bertuntunan Pukulan Tiga Kali}

Pada gerakan bertuntunan pukulan tiga kali, dimulai dengan menahan serangan atas menggunakan tangan kanan dan memasukkan pukulan bawah dengan tangan kiri menuju arah kemaluan. Selanjutnya, 
menahan serangan kaki menggunakan tangan kanan dan memasukkan pukulan menggunakan tangan kiri menuju pertengahan antara perut dan dada atau ulu hati. Kemudian mengarahkan pukulan ke arah tenggorokan menggunakan kanan.
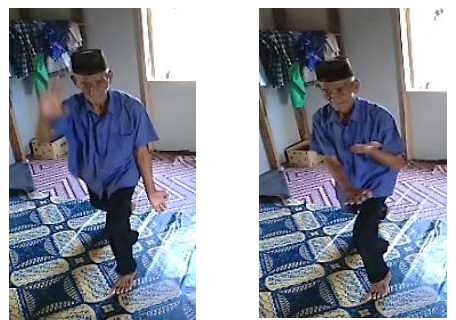

Gambar 12. Bertuntunan Pukulan Tiga Kali

\section{Mencakupkan Pukulan}

Pada gerakan mencakupkan pukulan, bermaksud untuk melakukan pukulan terakhir.

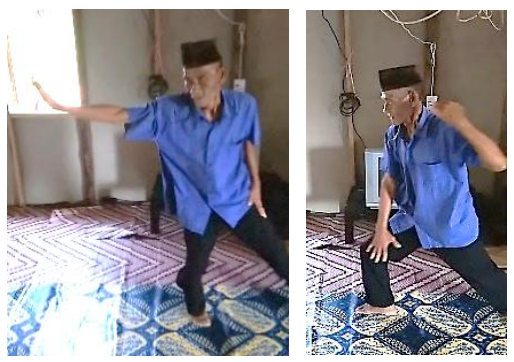

Gambar 13. Mencakupkan Pukulan

\section{Melakukan Pukulan}

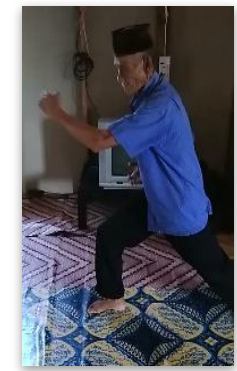

Gambar 14. Melakukan Pukulan

Gerakan melakukan pukulan dilakukan dengan dengan menggunakan sikap pasang kuda-kuda depan dengan kaki kanan sebagai tumpuan sedangkan kaki kiri berada selurus dibelakang kaki kanan dan tangan kiri ditekuk serong depan atas untuk melakukan pukulan.

\section{Melaksanakan}

Gerakan melaksanakan merupakan rangkaian terakhir dalam seni Hang Jebat. Gerakan ini dilakukan menggunakan tangan kanan dengan telapak tangan terbuka lebar mengarah ke dada dan menggunakan kudakuda depan dengan kaki kiri menjadi tumpuan di depan dan kaki kanan selurus dibelakang kaki kiri.

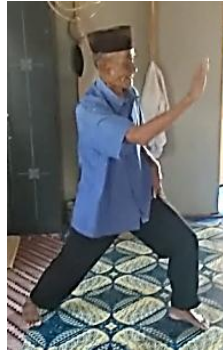

Gambar 15. Melaksanakan

Gerakan melaksanakan merupakan rangkaian terakhir dalam seni Hang Jebat. Gerakan ini dilakukan menggunakan tangan kanan dengan telapak tangan terbuka lebar mengarah ke dada dan menggunakan kudakuda depan dengan kaki kiri menjadi tumpuan di depan dan kaki kanan selurus dibelakang kaki kiri.

\section{Analisis Data}

Berdasarkan hasil penelitian yang diperoleh, peneliti melakukan analisis data dengan rancangan Spradley untuk memperoleh temuan etnomatematika yang sesuai dengan gerakan pukulan seni Pencak Silat. Dengan demikian, peneliti melakukan analisis data yang dipaparkan sebagai berikut:

\section{Analisis Domain}

Dari paparan hasil penelitian, peneliti menemukan satu buah domain Etnomatematika pada gerakan pukulan seni Pencak silat, yaitu domain bermain.

\section{Analisis Taksonomi}

Tahapan kedua dalam analisis data adalah analisis taksonomi. Berdasarkan domainnya, peneliti menentukan taksonomi atau tingkatan yang sesuai dengan domain bermain. Dengan demikian, hasil analisis taksonomi pada domain merancang adalah gerakan pukulan tangan dan gerakan kaki pada peragaan seni pencak silat 


\section{Analisis Komponensial}

Tahapan berikutnya dalam analisis data adalah analisis komponensial. Berdasarkan hasil analisis taksonomi, peneliti menentukan komponen yang sesuai pada domain bermain yaitu posisi gerak pukulan tangan dan posisi gerak kaki pada peragaan seni silat.

\section{Temuan Etnomatematika pada Gerakan Pukulan Seni Pencak Silat}

Tahapan selanjutnya dalam analisis data adalah analisis tema budaya. Analisis yang dilakukan yaitu menetapkan konsep matematika yang ditemukan pada domain bermain. Pada tahapan ini, peneliti memberikan gambaran mengenai temuan Etnomatematika terhadap konsep matematika yang ditemukan.

Dalam seni pencak silat Sendeng Cekak, memperagakan seni selain menggunakan alat berupa keris, juga menggunakan tangan kosong. Pada domain bermain, komponen yang ditentukan berdasarkan gerakan pukulan adalah posisi tangan dan posisi kaki. Pada komponen ini, diperoleh temuan etnomatematika yang dipaparkan sebagai berikut.
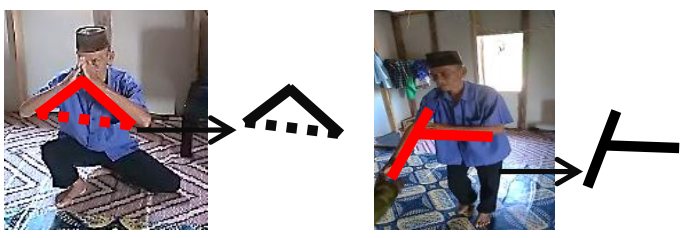

Gambar 16. Temuan Etnomatematika pada Gerakan Awal Hang Jebat

Berdasarkan Gambar 16, gerakan awal Hang Jebat digambarkan berbentuk bangun datar segitiga dan membentuk garis saling tegak lurus pada gerakan tangannya. Selanjutnya peneliti melakukan analisis pada konsep tersebut.

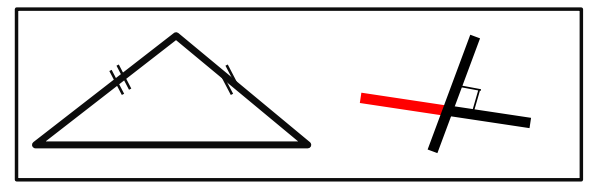

Gambar 17. Konsep Segitiga dan Garis pada Gerakan Awal Hang Jebat

Berdasarkan analisis pada Gambar 17, maka dapat disimpulkan bahwa gerakan yang dilakukan pada Gambar 16 terdapat konsep segitiga dan garis saling tegak lurus. Sifat-sifat dari segitiga yang ditemukan dijelaskan oleh Suharjana (2018) adalah sebagai berikut.
1) Segitiga sama kaki memiliki tepat dua sisi yang sama panjang

2) Dua buah garis dikatakan tegak lurus apabila pada perpotongan kedua garisnya membentuk sudut siku-siku $90^{\circ}$.

Berikutnya adalah temuan etnomatematika pada gerakan tangkisan.

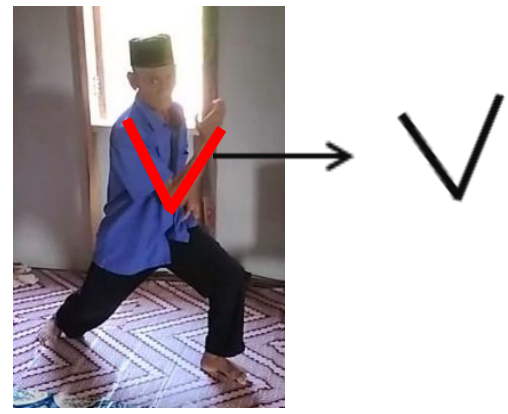

Gambar 18. Temuan Etnomatematika pada Gerakan Tangkisan

Berdasarkan Gambar 18, gerakan tangkisan digambarkan berbentuk sudut pada gerakan tangannya. Selanjutnya peneliti melakukan analisis pada konsep tersebut.

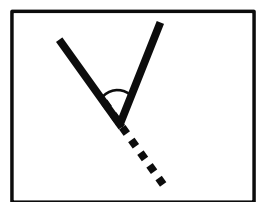

Gambar 19. Konsep Sudut pada Gerakan Tangkisan

Berdasarkan analisis pada gambar 19, maka dapat disimpulkan bahwa gerakan tangkisan pada Gambar 18 terdapat konsep sudut lancip. Sifat dari sudut lancip yang ditemukan dijelaskan oleh Suharjana (2018) adalah yaitu sudut lancip merupakan sudut yang besarnya kurang dari $90^{\circ}$.

Berikutnya adalah temuan etnomatematika pada gerakan tangkisan mengelak pukulan dalam.

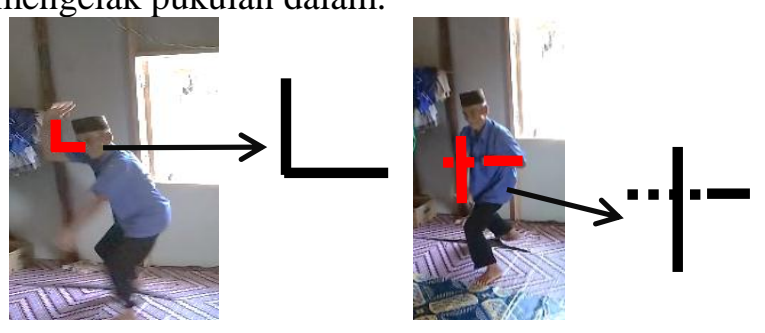

Gambar 20. Temuan Etnomatematika pada Gerakan Tangkisan Mengelak Pukulan Dalam 
Berdasarkan Gambar 20, gerakan tangkisan mengelak pukulan dalam digambarkan berbentuk sudut dan saling tegak lurus pada gerakan tangannya. Selanjutnya peneliti melakukan analisis pada konsep tersebut.

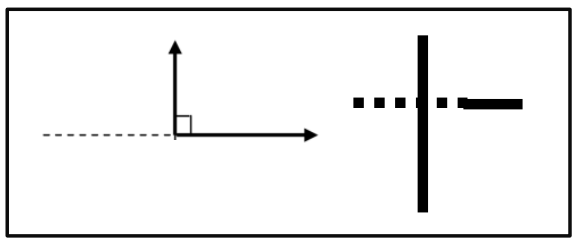

Gambar 21. Konsep Sudut dan Garis pada Gerakan Tangkisan Mengelak Pukulan Dalam

Berdasarkan analisis pada gambar 21, maka dapat disimpulkan bahwa gerakan tangkisan pada gambar 20 terdapat konsep sudut lancip. Sifat dari sudut siku-siku yang ditemukan dijelaskan oleh Suharjana (2018) adalah yaitu sudut siku-siku merupakan sudut yang besarnya tepat $90^{\circ}$.

Berikutnya adalah temuan etnomatematika pada gerakan membunuh pukulan.

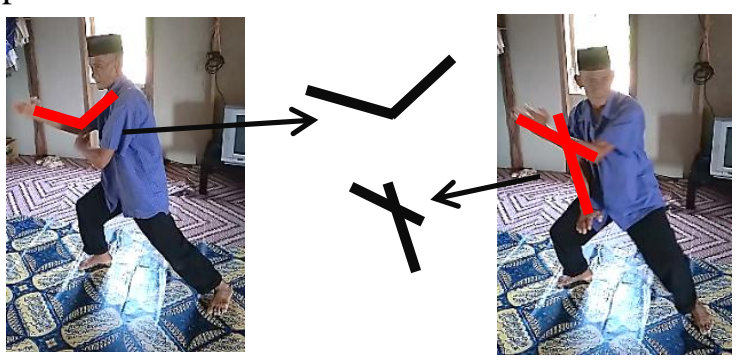

Gambar 22. Temuan Etnomatematika pada Gerakan Membunuh Pukulan

Berdasarkan Gambar 22, gerakan membunuh pukulan digambarkan berbentuk sudut dan garis berpotongan pada gerakan tangannya. Selanjutnya peneliti melakukan analisis pada konsep tersebut.

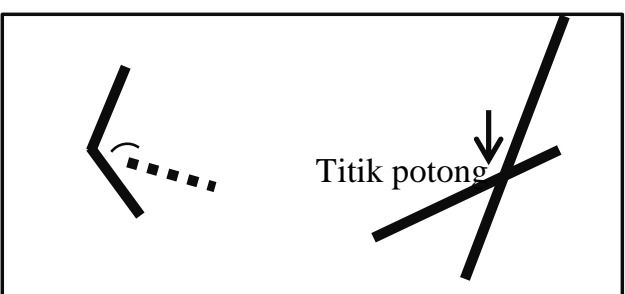

Gambar 23. Konsep Sudut dan Garis pada Gerakan Membunuh Pukulan
Berdasarkan analisis pada Gambar 23, maka dapat disimpulkan bahwa gerakan membunuh pukulan pada Gambar 22 terdapat konsep sudut tumpul dan garis berpotongan. Sifat dari sudut tumpul yang ditemukan dijelaskan oleh Suharjana (2018) adalah yaitu sudut lancip merupakan sudut yang besarnya lebih dari $90^{\circ}$ dan garis berpotongan yaitu kedua buah garis yang saling bertemu dan mempunyai titik potong.

Tabel 1. Rekapitulasi Hasil Temuan Etnomatematika Terhadap Konsep Matematika

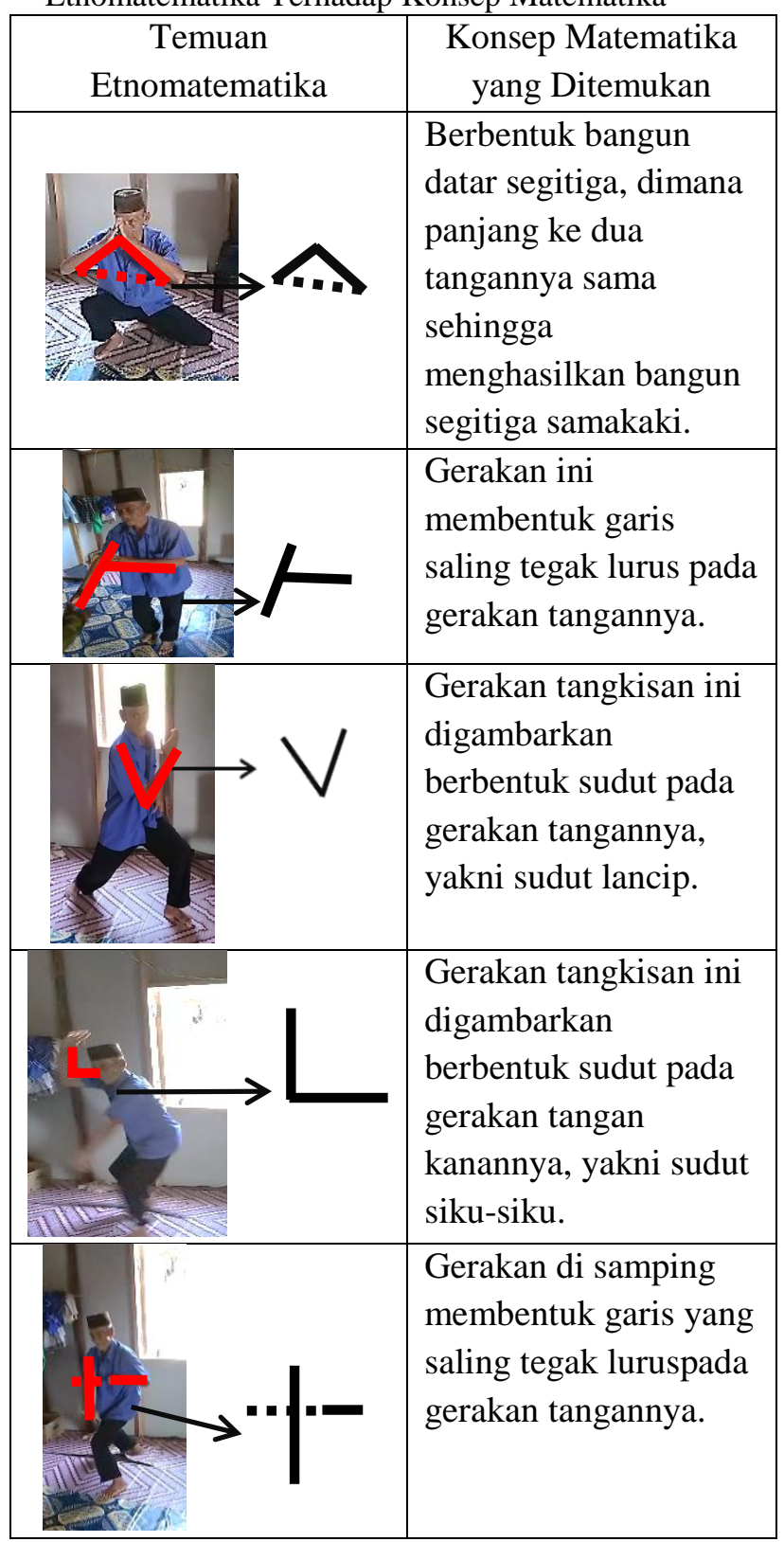




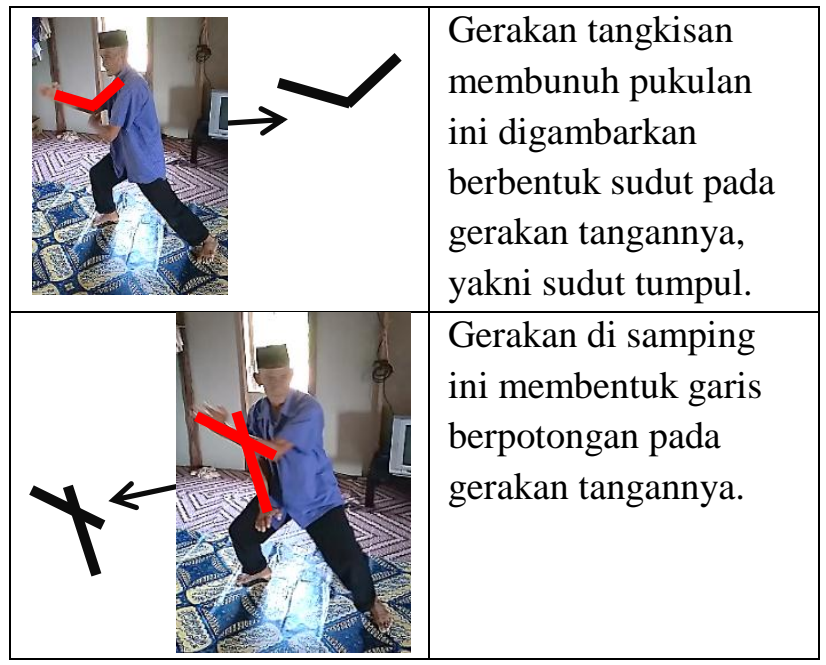

\section{KESIMPULAN}

Pada gerakan pukulan seni pencak silat, memuat domain atau aktivitas matematika yaitu domain bermain yang muncul pada saat peneliti melakukan proses analisis domain. Dari hasil analisis, diperoleh konsep matematika pada domain bermain yaitu konsep sudut lancip, sudut siku-siku, serta sudut tumpul, konsep segitiga, serta konsep garis berpotongan dan tegak lurus pada gerakan pukulan seni pencak silat.

Penggunaan contoh-contoh kontekstual dalam pembelajaran matematika sangat dibutuhkan untuk meningkatkan ketertarikan peserta didik dalam mengikuti pelajaran dan juga sebagai alternatif sumber belajar yang bervariatif. Dengan demikian, guru dapat memanfaatkan hasil eksplorasi pada gerakan pukulan seni pencak silat ini ke dalam materi pembelajaran matematika.

\section{UCAPAN TERIMA KASIH}

Terima kasih peneliti ucapkan kepada Bapak Rahmad dan Bapak Zul Rozali selaku narasumber, Ibu Dr. Nur Izzati, S.Pd., M.Si., dan Ibu Dra. Linda Rosmery T, M.Si., selaku dosen pembimbing yang telah memberikan kesempatan dan bersedia meluangkan waktu untuk membimbing dalam penulisan artikel ini, serta seluruh pihak terkait yang telah berpartisipasi, memberikan masukan serta saran sehingga artikel ini dapat diselesaikan dengan baik dan tepat waktu.

\section{REFERENSI}

Afriyanty, M., \& Izzati, N. (2019). Eksplorasi etnomatematika pada corak alat musik kesenian marawis sebagai sumber belajar matematika. Jurnal Gantang, Vol.4 No.1, 39-48.

Atmidasari, S. (2017). Kajian Etnomatematika Pembagian Harta Waris pada Masyarakat Lampunf Ditinjau dari Perspektif Adat. Skripsi. Pendidikan Matematika Universitas Islam Negeri Raden Intan, Lampung.

Creswell, J. W. (2012). Educational research: planning, conducting, and evaluating quantitative and quailtative research. New Jersey: Person Education, Inc.

Desmawati, R. (2018). Eksplorasi Etnomatematika pada Gerak Tari Tradisional Sigeh Pengunten Lampung. Skripsi. Pendidikan Matematika Fakultas Tarbiyah dan Keguruan Universitas Islam Negeri Raden Intan, Lampung.

Febrian. (2016). Recognizing ethnomathematics in wau kite and corak-ragi of tenun melayu from kepulauan riau province and using its potentials towards learning of school mathematics. Proceedings of The 2nd SULE - IC, FKIP, UNSRI, Palembang, Vol.2 No.1, 337-258.

Lestari, K. E., \& Yudhanegara, M. R. (2015). Penelitian pendidikan matematika. Bandung: Refika Aditama.

Mulyana. (2013). Pendidikan pencak silat. Bandung: Remaja Rosdakarya.

Nuh, Z. M., \& Dardiri. (2016). Etnomatematika dalam sistem pembilangan pada masyarakat melayu riau. Kutubkhanah Jurnal Penelitian Sosial Keagamaan UIN Sultan Syarif Kasim Riau, Vol.19 No.2, 220-238.

Nurhikmah, S., Febrian \& Fera, M. (2019). Eksplorasi etnomatematika pada ragam corak ukiran khas melayu kepulauan riau. Jurnal Kiprah, Vol.VII No.1, 41-48. 
Sarwono, J. (2006). Metode penelitian kuantitatif \& kualittatif. Yogyakarta: Graha Ilmu.

Sirate, S. F. S. (2011). Studi kualitatif tentang aktivitas etnomatematika dalam kehidupan masyarakat tolaki. Lentera Pendidikan, 14 No. 2, 123-136.

Sugiyono. (2012). Metode penelitian pendidikan pendekatan kuantitatif, kualitatif, dan rnd. Bandung: Alfabetha.

Suharjana, A. (2018). Pengenalan bangun datar dan sifat-sifatnya di SD. Yogyakarta:

Pusat Pengembangan dan

Pemberdayaan Pendidik dan Tenaga Kependidikan Matematika.

Suhartono. (2011). Buku pelajaran pencak silat nusantara: program beladiri praktis. Jakarta: Keluarga Pencak Silat Nusantara.

TIM. (2008). Kamus Bahasa Indonesia. Departemen Pendidikan Nasional, Jakarta. 